\title{
OPTIMAL HOLDINGS OF INTERNATIONAL RESERVES: SELF-INSURANCE AGAINST SUDDEN STOP
}

\author{
Guillermo A. Calvo \\ Alejandro Izquierdo \\ Rudy Loo-Kung \\ Working Paper 18219 \\ http://www.nber.org/papers/w18219 \\ NATIONAL BUREAU OF ECONOMIC RESEARCH \\ 1050 Massachusetts Avenue \\ Cambridge, MA 02138 \\ July 2012
}

The views expressed herein are those of the authors and do not necessarily reflect the views of the National Bureau of Economic Research nor those of the Inter-American Development Bank.

NBER working papers are circulated for discussion and comment purposes. They have not been peerreviewed or been subject to the review by the NBER Board of Directors that accompanies official NBER publications.

(C) 2012 by Guillermo A. Calvo, Alejandro Izquierdo, and Rudy Loo-Kung. All rights reserved. Short sections of text, not to exceed two paragraphs, may be quoted without explicit permission provided that full credit, including $(\mathcal{C}$ notice, is given to the source. 
Optimal Holdings of International Reserves: Self-Insurance against Sudden Stop

Guillermo A. Calvo, Alejandro Izquierdo, and Rudy Loo-Kung

NBER Working Paper No. 18219

July 2012

JEL No. E42,E58,F15,F31,F32,F33,F41

\begin{abstract}
This paper addresses the issue of the optimal stock of international reserves in terms of a statistical model in which reserves affect both the probability of a Sudden Stop-as well as associated output costs-by reducing the balance-sheet effects of liability dollarization. Optimal reserves are derived under the assumption that central bankers conservatively choose reserves by balancing the expected cost of a Sudden Stop against the opportunity cost of holding reserves. Results are obtained without using calibration to match observed reserves levels, providing no a priori reason for our concept of optimal reserves to be in line with observed holdings. Remarkably, however, observed reserves on the eve of the global financial crisis were-on average-not distant from optimal reserves as derived in this model, indicating that reserve over-accumulation in Emerging Markets was not obvious. However, heterogeneity prevailed across regions: from a precautionary standpoint, Latin America was closest to model-based optimal levels, while reserves in Eastern Europe lay below optimal levels, and those in Asia lay above. Nonetheless, there are other motives for reserve accumulation: we find that differences between observed reserves and precautionary-motive optimal reserves are partly explained by the perceived presence of a lender of last resort, or characteristics such as being a large oil producer. However, to a first approximation, there is no clear evidence supporting the so-called neo-mercantilist motive for reserve accumulation.
\end{abstract}

Guillermo A. Calvo

Columbia University

School of International and Public Affairs

420 West 118th St, Room 1303B

MC3332

New York, NY 10027

and NBER

gc2286@ columbia.edu

Alejandro Izquierdo

Inter-American Development Bank

1300 New York Ave, N. W.

Washington, D. C., 20577

alejandroi@iadb.org
Rudy Loo-Kung

Inter-American Development Bank

1300 New York Ave, N. W.

Washington, D. C., 20577

rudyl@iadb.org 


\section{Introduction}

Recent financial crises in both emerging and advanced economies show the increasing fragility of financial markets and institutions in the last three decades. Fragility could arguably be partially explained by a wave of financial deregulation and regulation arbitrage, the latter leading to a "race to the bottom" by which financial instruments are designed to avoid costly regulatory requirements. The latter was evident in the context of the "subprime crisis" in which "shadow banks" could become highly leveraged by (legally) eschewing regulations applied to banks protected by central banks - although they were eventually protected by central banks on the principle that they were "too big to fail," a clear case of moral hazard.

Financial fragility was until recently ignored by mainstream macroeconomics under the presumption that the issues involved could be handled by specialists focusing on micro issues and, if it occasionally overflowed its micro niche and threatened to cause severe output and employment effects, standard macroeconomic policies (e.g., lower policy interest rates) would be able to restore full-employment equilibrium in a short span of time. Recent episodes, though, leave no doubt that financial fragility could result in a major interruption of credit flows in spite of strenuous efforts to prevent it through standard macro policy. Credit stop brings severe cuts in working capital and investment funds, resulting in significant loss in output and employment.

Emerging market economies, EMs, have suffered a large number of these episodes. One salient characteristic in EMs is a sudden, large and largely unexpected cut in international capital flows, a phenomenon that has been labeled "Sudden Stop." Without anything resembling a Global Lender of Last Resort and, the limited ability of EMs to borrow in terms of domestic currency both internationally and domestically, make EMs particularly vulnerable to Sudden Stops and, outstanding examples of financial fragility.

Despite multiple official pronouncements about the need to find a new 'Financial Architecture,' particularly after the surprising collapse of the Asian Tigers in 1997, little was done to improve the resilience of EMs against Sudden Stops. This gave EM policymakers strong incentives to self-insure by accumulating International Reserves. The resilience of the high-reserves economies during the subprime crisis appears to validate the self-insurance strategy. Part of the 
adjustment during the Lehman crisis episode, for example, took the form of reserve decumulation.

International reserves take the form of hard-currency liquid public liabilities (e.g., US Treasury securities), typically exhibiting low rates of return compared with other investment projects opened to EMs. Thus, even though it is hard to deny the relevance of reserve accumulation for shielding EMs from the effects of Sudden Stop, the present large stocks and continued trend towards greater accumulation of International Reserves is beginning to raise the question of whether this self-insurance strategy has already reached a point of strongly declining marginal returns - and becoming "excessive."

This paper addresses the issue of the optimal stock of International Reserves in terms of a statistical model in which reserves affect both the probability of Sudden Stop, and attendant output costs. This allows us to compute the expected return from International Reserves holdings, conditional on global financial conditions. On the other hand, the opportunity cost of International Reserves is assumed to be equal to the spread of public sector bonds over the interest earned from holding reserves. These two pieces of information are employed to compute the level of reserves that maximize expected return net of cost, given global financial conditions. Our main results suggests that over-accumulation of reserves in EMs is not obvious. Out of the 27 emerging economies considered, only 10 displayed observed reserves that were higher than their corresponding optimal level prior the global financial crisis. Also, our empirical evidence seems to indicate that currency-denomination mismatch and current account deficits - identified in Calvo, Izquierdo and Mejia (2008) as key determinants of Sudden Stops - are a substantial element taken into account by policymakers in choosing the stock of International Reserves. However, other motives for deviating from optimal International Reserves levels associated to the precautionary motive highlighted here are also present. Some of the empirical evidence presented below suggests that oil exporting countries may hold reserves in excess of optimal reserves based on precautionary motives, perhaps as an instrument for inter-temporal transfers of oil resources. Also, perceptions of lender-of-last-resort type insurance may also explain deviations from precautionary-motive-type optimal reserves levels. 
The paper is organized as follows: Section II reviews the literature on this topic, Section III presents a model based on precautionary motives, Section IV discusses empirical results, and Section V concludes.

\section{Literature}

The substantial increase in international reserves in several emerging markets following Sudden Stop episodes throughout the 1990s motivated the resurgence of interest in models linking international reserve hoarding to precautionary motives. Although the source of shocks may now be different, the concept of holding international reserves for precautionary reasons is not new and it can be traced back to Heller (1966), who motivates the need for holding reserves by introducing shocks to the trade balance-e.g., a fall in foreign demand for a country's exportsalthough his framework can accommodate any kind of external imbalance. Heller's work is about the first to quantify optimal reserve levels for a large set of countries by weighting the adjustment costs resulting from external imbalances that cannot be met with reserves against the opportunity cost of holding reserves. ${ }^{1}$

Another family of models accounting for reserve holdings that emerged later is based on stochastic inventory-theoretic frameworks borrowed from setups modeling money holdings (such as Miller and Orr (1966)). One of the first approaches in this direction came from Frenkel and Jovanovic (1981), who view reserves as a buffer stock to accommodate stochastic fluctuations in external transactions. Since adjustment costs will be incurred whenever reserves reach a lower bound, it will be optimal to hold a level of reserves that can cope with the volatility of external transactions and avoid such adjustment. In this setup, optimal reserves are a function of the cost of adjustment, the opportunity cost of holding reserves, and the volatility of Wiener increments in the reserve process. Empirical modifications, as in Flood and Marion (2002), improved on Frenkel and Jovanovic (1981) by measuring reserve volatility more precisely.

A reformulation of the precautionary approach was brought back to the forefront by Ben-Bassat and Gottlieb (1992), who consider that a drain of reserves can lead to default on external debt with subsequent output losses. Thus, it is the cost of default that must be incorporated in the trade-off against the opportunity cost of holding reserves.

\footnotetext{
${ }^{1}$ The size of adjustment is measured by the amount of average external imbalances relative to the propensity to import, while the opportunity cost of holding reserves is measured as the difference between the rate of return on capital and the return on international reserves.
} 
More recently, Lee (2004), based on option price theory, estimates the optimal level of international reserves under the assumption that an overall insurance value equivalent to the amount of short-term external debt is needed for precautionary reasons. Further assuming that this overall insurance level will be met partially through market-based insurance and partially by self-insurance- i.e., reserve accumulation-he derives optimal self-insurance levels for developed countries. ${ }^{2}$ Using this as a benchmark, he contrasts existing reserve levels in developing countries against those that they would hold were they to behave like developed countries-covering roughly about 50 percent of short-term external debt through reserve accumulation- and finds that for a group of emerging markets, excess reserves amount on average to 17 percent of GDP. He attributes this excess coverage to the weakness in institutional development and policy credibility in emerging markets. ${ }^{3}$

Dooley, Folkerts-Landau and Garber (2005) take a different view and follow a modern mercantilist approach to account for hoarding of international reserves as part of a deliberate development strategy, in which reserves act as collateral for encouraging foreign direct investment. However, Aizenman and Lee (2005) find preliminary support for the fact that although mercantilist effects are significant-as captured by variables like export growth, or deviations of the real exchange rate from purchasing power parity-they have a smaller impact relative to variables associated with precautionary effects (such as crisis indicators) in the determination of the level of reserves.

Focusing again on the precautionary approach, Jeanne and Ranciere (2006) provide an up-to-date motivation for international reserve accumulation by constructing a model that incorporates the benefit of holding international reserves in sustaining domestic absorption in times of a Sudden Stop in capital flows. In order to obtain empirical estimates of optimal reserves, they calculate the expected costs associated with a Sudden Stop by estimating a Probit model of the probability of a Sudden Stop-based on a set of macroeconomic variables-and taking a proxy for the cost of

\footnotetext{
${ }^{2}$ The motive for partial self-insurance relies on the assumption that there exists a spread between the country's borrowing rate and the interest rate available to the party offering insurance.

${ }^{3}$ Aizenman and Marion (2004) provide another rationale for the existence of reserve levels below those deemed optimal by efficiency conditions when political economy factors are taken into account. For example, a conservative government with a low probability of reelection may want to leave a smaller reserve level to "soft" contenders who might spend them later on special interest groups. However, Aizenman and Marion (2002) show that other factors, such as increased sovereign risk and high taxation costs associated with large inelastic fiscal liabilities may lead to larger reserve accumulation.
} 
a Sudden Stop constructed as the sample average difference in the output growth rate in Sudden Stop times relative to tranquil times. With these expected costs at hand, a measure of the opportunity cost of holding reserves, a calculation of the average size of capital account reversals, and an assumption on the degree of risk aversion of the government, they obtain a level of optimal reserves for the average country. However, when moving to regional averages, they estimate an optimal level of reserves for each country by setting the size of the Sudden Stop to its realized mean value in each region, keeping the cost of a Sudden Stop constant, while calibrating the coefficient of risk aversion to match average reserve holdings in the middle of the sample period. Although their model is useful in incorporating reserves as an instrument that stabilizes domestic absorption, their approach does not incorporate a role for reserves either in affecting the probability of a Sudden Stop or the cost of a crisis.

Ruiz-Arranz and Zavadjil (2008) follow on the steps of Jeanne and Ranciere (2006) to address their claim that reserve holdings by Asian countries seem to lie above optimal levels. By acknowledging that the size of the costs of Sudden Stops was larger in Asia than that used by Jeanne and Ranciere (2006), and that these economies faced lower spreads, they could explain a significant amount of the difference between the levels of observed and optimal reserves as defined by Jeanne and Ranciere (2006). However, in their estimations, they take both the probability of a Sudden Stop as well as the cost of the crisis to be exogenous.

Gonçalves (2007) extends the framework in Jeanne and Ranciere (2006) to include coverage of dollar deposit withdrawals during a Sudden Stop as an additional element to consider at the time of choosing optimal reserves, and assumes that banks match with their own reserves the equivalent of dollar deposits from non-residents, but only a fraction of dollar deposits in the hands of residents, providing an additional role for government reserve accumulation. However, this framework does not incorporate either a role for reserves either in affecting the probability of a Sudden Stop or the cost of a crisis.

To our knowledge, one of the few studies on optimal reserves that incorporate international reserves in the determination of the probability of a crisis is that of Garcia and Soto (2004), who use the ratio of reserves to short-term liabilities in their estimations. They provide a rationale for this by suggesting that larger amounts of international reserves could imply that countries avoid costly liquidation of assets. They proceed to estimate optimal reserves for a group of four Asian 
economies and Chile, under alternative assumptions about the costs of a crisis, ranging from 5\% to $15 \%$ of GDP. Alternatively, they ask what the costs of a crisis should be for current levels of reserves to be considered optimal. However, the mechanism under which reserve hoarding operates in reducing the probability of a Sudden Stop is not explicitly stated, and indicators of external liabilities, a factor that could be considered relevant in terms of providing a source of risk justifying the need to accumulate reserves, turn out not to be significant in their estimations. Moreover, just like most of the literature, their specifications of optimal reserves do not rely on estimations of determinants of the cost of a crisis-including international reserves-but rather rely on sensitivity analysis to alternative sizes of the costs of a crisis.

More recently, Jeanne (2007) also incorporates international reserves as a determinant of the probability of crises, but finds that although they do help in mitigating the probability of currency crises, they do not affect significantly the probability of a Sudden Stop. ${ }^{4}$

Our approach builds on this precautionary approach literature linked to Sudden Stops and makes the following contributions: we endogenize both the probability of a Sudden Stop and the costs of a crisis through empirical models linked to balance-sheet effects. Moreover, we provide a rationale for the inclusion of international reserves in the determination of the probability of a Sudden Stop as well as output costs, as reserves constitute an instrument that offsets potential balance-sheet effects stemming from large Domestic Liability Dollarization (DLD). ${ }^{5}$ In this sense, determinants of the probability of a crisis - including international reserves - are in and of themselves also determinants of the cost of a crisis. This approach is entirely consistent with the theoretical framework developed by Durdu, Mendoza and Terrones (2007), who argue that foreign asset accumulation is justified by optimal self-insurance due to the risk of endogenous Sudden Stops in economies with liability dollarization and collateral constraints. In their model, precautionary demand for foreign assets takes into account how foreign asset holdings alter the probability and the magnitude of Sudden Stops, both of which are equilibrium outcomes of their model.

\footnotetext{
4 These estimations are also used in an updated version of Jeanne and Ranciere (2009), incorporating the impact of reserves in the probability of a currency crisis.

${ }^{5}$ DLD consists of dollar loans handed by the domestic banking system as a share of GDP. See Calvo, Izquierdo and Mejia (2008) for details.
} 
Another benefit of our approach is that instead of selecting parameters to calibrate a first-order condition to match average data on costs and reserve holdings, we tailor both the probability of a Sudden Stop and output costs functions to country specific information on their determinants based on empirical models. We then use our first-order condition to put these pieces together, without requiring further assumptions on parameters. In a way, this approach to obtaining optimal levels of international reserves is more ambitious in that it will not necessarily "fit" the data. However, assumptions will need to be made regarding the level of insurance policymakers may want to buy when deciding on the optimal level of reserves.

\section{The model}

Our point of departure relies on the assumption that international reserves serve two key purposes. On the one hand, they may affect the probability of a Sudden Stop in capital flows. On the other, they may have an influence on the costs associated with a financial crisis. In this case, the central bank will need to decide on a level of international reserves that weighs the impact of reserve accumulation on the expected costs of a Sudden Stop against the opportunity cost of holding reserves. Consider the case in which the monetary authority minimizes the following loss function $\mathrm{L}(\mathrm{R})$ :

$$
L(R)=P(S S=1 \mid R) K(R \mid S S=1)+\rho R,
$$

where $R$ are international reserves as a share of output, $P(S S=1 \mid R)$ is the probability of a Sudden Stop conditional on reserves $\mathrm{R}, K(R \mid S S=1)$ is the output cost conditional on the occurrence of a Sudden Stop, and $\rho R$ is the opportunity cost of holding reserves, where $\rho$ is the spread of public bonds over interest earned from holding reserves. ${ }^{6}$ Assume further that both the probability of a Sudden Stop and the output cost are a function of international reserves -i.e., $\mathrm{P}(\mathrm{SS}=1)=\mathrm{F}(\mathrm{R})$ and $\mathrm{K}(\mathrm{SS}=1)=\mathrm{K}(\mathrm{R})$. In this case, we formally define optimal reserves $\left(\mathrm{R}^{*}\right)$ as:

$$
R^{*} \equiv \underset{R>0}{\arg \min } L(R)=F(R) K(R)+\rho R
$$

Any interior solution must then satisfy first-order condition:

\footnotetext{
${ }^{6}$ This modeling choice carries the assumption that the government can choose between paying back debt (in which case it foregoes interest payments at the ongoing public bond rate), or holding reserves (in which case it earns the risk free rate).
} 


$$
F^{\prime}\left(R^{*}\right) K\left(R^{*}\right)+K^{\prime}\left(R^{*}\right) F\left(R^{*}\right)+\rho=0
$$

For the particular case in which $\mathrm{F}(\mathrm{R})$ is obtained from estimation of a Probit model, and cost function $K(R)$ is linear in $R$, or:

$$
F(R)=\int_{-\infty}^{\alpha R} \frac{1}{\sqrt{2 \pi}} e^{-t^{2} / 2} d t, \quad K(R)=\phi R
$$

then equation (3) becomes:

$$
\frac{\alpha \phi}{\sqrt{2 \pi}} e^{-\left(\alpha R^{*}\right)^{2} / 2} R^{*}+\phi \int_{-\infty}^{\alpha R^{*}} \frac{1}{\sqrt{2 \pi}} e^{-t)^{2} / 2} d t+\rho=0
$$

which implicitly defines a level of optimal reserves $R^{*}$. To ensure that this level of reserves is optimal, second order conditions require:

$$
\frac{\alpha \phi}{\sqrt{2 \pi}} e^{-\left(\alpha R^{*}\right)^{2} / 2}\left(2-\alpha^{2} R *^{2}\right)>0
$$

which, under the assumption that $\alpha<0$ and $\varphi<0$, requires:

$$
R *^{2}<2 / \alpha^{2}
$$

Empirical counterparts of optimal reserves consistent with the framework above thus require estimation of a Probit model describing the likelihood of a Sudden Stop, as well as a model linking output costs of Sudden Stops to international reserves and other potentially relevant explanatory variables.

\section{Empirical estimations}

Work by Calvo, Izquierdo and Mejia (2008) suggests that Domestic Liability Dollarization (DLD), together with potential changes in the real exchange rate (RER) following a Sudden Stop-proxied by the RER that would bring the current account deficit to zero-are key determinants of the probability of a systemic Sudden Stop, capturing potential balance-sheet 
effects following a crisis in foreign financing. ${ }^{7}$ However, their work does not consider the potential impact that the holding of international reserves could have in offsetting the hazard caused by DLD. To explore this potential offsetting effect, we build on their estimations, but introduce the concept of net DLD, which subtracts holdings of international reserves from measures of DLD. Thus, we estimate Probits of the type:

$$
P\left(S S_{t}=1\right)=\Phi\left(\alpha_{0}+\alpha_{1}\left(1-\omega_{t-1}\right)+\alpha_{2}\left(N e t D L D_{t-1}\right)+X \beta+\sum_{i} \eta_{i} t i m e_{-} d u m_{i}\right)
$$

where a systemic Sudden Stop (SS) is defined as a fall in capital flows exceeding two standard deviations below the mean that coincides with a spike in regional spreads (or a "systemic" Sudden Stop), $\Phi($.$) is the standard normal cumulative distribution, Net DLD represents DLD net$ of international reserves, (1- $\omega)$ represents the change in RER that results from a stop in financing of the current account deficit, and $\mathrm{X}$ is a set of control variables such as foreign direct investment, portfolio integration, terms of trade growth, government balance, the exchange rate regime, the ratio M2-to-reserves and foreign debt as a share of GDP. ${ }^{8}$ In order to reduce potential endogeneity problems, all variables are lagged one period. ${ }^{9}$ A set of yearly time dummies (time_dum) is also included to reflect changing external conditions. Using the same database as in Calvo, Izquierdo and Mejia (2008), covering 110 countries for the period $1992-$ 2004 we produce a set of estimations shown in Table 1. Interestingly, the coefficient accompanying Net DLD is significant at the one percent level across estimations, validating the relevance of international reserves in reducing the likelihood of a Sudden Stop. ${ }^{10}$

The second component of this empirical approach to optimal reserve determination requires estimation of an output cost function dependent on reserve holdings. It could be argued that a cut in foreign currency financing hitting firms indebted in that currency-leading to a cut in production or outright default as a consequence of sizeable balance-sheet effects-could be

\footnotetext{
${ }^{7}$ DLD consists of dollar loans handed by the domestic banking system as a share of GDP. See Calvo, Izquierdo and Mejia (2008) for details.

${ }^{8}$ See the appendix for a description of the abovementioned variables and sources used. A more precise definition of the measure of systemic Sudden Stop used here can be found in Calvo, Izquierdo and Mejia (2008).

${ }^{9}$ Following Calvo, Izquierdo and Mejia (2008), we carried out a Rivers-Vuong test to control for the potential endogeneity of $(1-\omega)$ with the latent variable behind Sudden Stops (capital flows). With this methodology, the results obtained in the standard Probit estimation shown here hold. Results are available upon request.

${ }^{10}$ It could be argued that netting out reserves from DLD is not straightforward and indeed DLD and reserves could be included separately in Probit estimations. It turns out that when both variables are included separately, the coefficients accompanying both variables are not statistically different from each other as indicated by appropriate tests.
} 
ameliorated by the provision of central bank lending in hard currency through the use of previously accumulated international reserves. As a matter of fact, this policy has been widely used by countries like Brazil with successful results during the recent financial crisis of 2008/9.

Estimation of such a cost function first requires defining output costs. Most approaches in the literature discussed above work with measures concentrating on the average fall in output in the aftermath of the crisis. However, these measures do not incorporate differences relative to trend (with the exception of Ruiz-Arranz and Zavadjil (2008)), something that we believe is more appropriate and that we incorporate in our estimations below. We proceed as follows: first, for each country included in our Probit estimation, we compute the present discounted sum of any contiguous negative output gaps measured as the percentage difference between observed GDP and its corresponding HP trend. ${ }^{11}$ For each episode, we denote $T$ as the period immediately prior to GDP falls below trend. With this information at hand, we then select those episodes in which a Systemic Sudden Stop occurs in a 3-year window centered at $T$, so that the selected episodes correspond to falls in output that occur after or at the time of a Systemic Sudden Stop. ${ }^{12}$

Figure 1 depicts the estimated costs of crisis for the group of countries in our sample that experienced a systemic Sudden Stop anytime between 1992 and 2004. It identifies 45 cases, with output costs ranging from 0.3 to 38.8 percent of GDP.

With output costs defined, we proceed to estimation of a simple equation of determinants of these costs, using a regression of the type:

$$
K_{T, i}=\phi_{0}+\phi_{1}\left(1-\omega_{T, i}\right)+\phi_{2}\left(\operatorname{NetDLD} D_{T, i}\right)+X_{T, i} \gamma+\sigma S h o c k S i z e+\varepsilon_{T, i}
$$

Where $K_{T, i}$ represents output costs as previously defined for country $i$. These costs are considered to be a function of a country's vulnerability to Sudden Stops. To the extent that investor predictions are right in the sense that the factors describing the vulnerability to a Sudden Stop as shown in equation (8) are valid, then these same factors could be a good predictor of the size of a crisis as well (thus, we include $(1-\omega)_{T, i}$, Net $D_{L D}$, as well as the set of control

\footnotetext{
${ }^{11} \mathrm{HP}$ trends are calculated over the 1980-2010 period. If anything, this methodology tends to underestimate output losses, as HP trends will tend to accompany falls in output rather mechanically when, in fact, underlying factors determining output trends may not vary significantly. We use a discount factor of $10 \%$.

${ }^{12}$ More precisely, this concept requires that a Systemic Sudden Stop occur in between T- 1 and T+1. This requirement intends to select those output fall episodes in which a causal relation can be inferred.
} 
variables $\left(\mathrm{X}_{\mathrm{T}, \mathrm{i}}\right)$ included in the estimation of equation (8)). This is particularly evident with measures such as NetDLD: since large foreign currency liabilities could lead to economy-wide bankruptcies and output collapse in the event of a Sudden Stop-making debt repayment quite improbable-then it is quite likely that this factor will also be a good predictor of the probability of a Sudden Stop. Thus, NetDLD could be in and of itself a determinant of both the probability of a cut in financing as well as a good predictor of the costs associated with a Sudden Stop.

To control for the size of the different systemic shocks throughout our sample, we include the change in the aggregate EMBI Plus spread before and after each Systemic Sudden Stop associated with a fall in output. ${ }^{13}$ Results are shown in Table 2, and they indicate that net DLD levels on the eve of a fall in output associated with a Sudden Stop is a relevant factor behind output costs in the aftermath of a Sudden Stop (significant at the 1 to 5 percent level, depending on controls included in the specification). So is the prevailing budget balance before output collapse, which remains significant at the 1 percent level in most specifications. Measures of portfolio integration before the crisis are also significant at the 5 to 10 percent level, depending on the specification used, indicating that larger integration-presumably without appropriate accompanying institutions-may lead to larger output costs in the event of a Sudden Stop. Our proxy for the size of the shock also remains significant at the 5 to 10 percent level. However, unlike Probit estimations, (1- $\omega)$ is not significant. One potential explanation for this is that, while current account deficits-the key factor behind the (1- $\omega)$ measure-may be good predictors of the likelihood of a crisis, adjustment processes in the current account balance differ from country to country, making it difficult for this measure to account statistically for developments in the aftermath of the crisis. Taken altogether, these results are considerably good when taking into account that the sample includes only 37 observations, given the infrequent nature of Systemic Sudden Stops.

Estimation of a cost function such as that in equation (9) is no easy task because the size of output costs is typically affected by policy responses from domestic governments during the crisis. However, as mentioned in Ortiz, Ottonello, Talvi, and Sturzenegger (2009) when

\footnotetext{
${ }^{13}$ Notice that the change in EMBI spreads corresponds to the aggregate EMBI spread, i.e., the average EMBI spread comprising all Emerging Markets in the sample. This is done in order to capture as much as possible differences in EMBI spreads that are not due to developments in a particular country, but rather, changes in international liquidity available to Emerging Markets. A similar measure is obtained for the average European sovereign spreads over German bonds. See Calvo, Izquierdo and Mejia (2008) for more details.
} 
analyzing the effects of expansionary policies in the aftermath of a Sudden Stop, the ability of governments to respond to a crisis will depend on pre-existing vulnerabilities as well as the size of the shock, making estimation of equation (9) with the inclusion of post-shock policy responses more cumbersome due to potential endogeneity issues. Despite the limitation of not having included precise measures of monetary and fiscal response to the crisis in the estimation of equation (9), there is reason to believe that two key variables included in the estimation-i.e., Net DLD , as well as the prevailing government balance before the fall in output-could be reasonable proxies. ${ }^{14}$ First, the tight significance of Net DLD in determining output costs may be capturing the fact that-besides being a measure of the financial burden associated with a Sudden Stop-NetDLD can be interpreted as an indicator of limitations to expansionary monetary policies-given the increased costs that devaluation stemming from lax monetary conditions would bring. As such, it can be interpreted as a good proxy for limitations to the size of expansionary monetary policies in the aftermath of the crisis. Similarly, the tight significance of the pre-crisis government balance can also be rationalized once it is acknowledged that it can represent a proxy of the ability to conduct expansionary fiscal policy in the years ahead.

With empirical estimates of equations (8) and (9) at hand, it is now possible to put them together at work in the determination of an optimal level of international reserves that is dependent on country-specific factors and the size of Sudden Stops. ${ }^{15}$ Given that we are using additional controls in Probit estimations than just international reserves, we modify equation (5)-pinning down optimal reserves - to account for this, such that:

$$
\frac{\alpha_{2}}{\sqrt{2 \pi}} e^{-A^{2} / 2} B+\phi_{2} \int_{-\infty}^{A} \frac{1}{\sqrt{2 \pi}} e^{-t)^{2} / 2} d t+\rho=0
$$

where:

$$
A=\alpha_{0}+\alpha_{1}(1-\omega)+\alpha_{2}(N e t D L D)+X \beta+\bar{\eta},
$$

\footnotetext{
${ }^{14}$ These proxies preceding the crisis are also less likely to be endogenous with the costs of a Sudden Stop.

${ }^{15}$ We measure the opportunity cost of holding reserves as the 1991-2007 average of JP Morgan's EMBI+ sovereign spread.
} 


$$
B=\phi_{0}+\phi_{1}\left(1-\omega_{T, i}\right)+\phi_{2} \operatorname{NetDLD} D_{T, i}+X_{T, i} \gamma+\sigma \text { ShockSize, }
$$

$$
N e t D L D=D L D-R^{*},
$$

$\bar{\eta}$ is the estimated coefficient of the time dummy that the policymaker believes reflects global financial conditions, and $\mathrm{R}^{*}$ is the optimal level of reserves. With equations (10)-(13) at hand, it is possible to estimate the level of optimal reserves while controlling for other factors affecting both the probability and the cost of a Sudden Stop. Using the estimated parameters based on the Calvo, Izquierdo and Mejía (2008) database, we calculate the optimal level of international reserves as of 2007 for a set of 27 Emerging Economies (listed in Table 3) for which we were able update the relevant variables used in estimations, with the purpose of assessing how well prepared these Emerging Economies were to withstand the global financial crisis that ensued in 2008/2009. Since much of the debate on potentially excessive reserve accumulation has revolved around Emerging Markets, we focus on economies that belong to JP Morgan's Emerging Market Bond Index.

A last element to consider in order to compute optimal reserves at each point in time is that, although country-specific variables used in both Probit and output costs estimations can be chosen for each point in time, a decision that remains to be made relates to the size of the shock for which countries will insure when deciding on their optimal reserve level. Moreover, it must also be recognized that policymakers may face uncertainty in choosing amongst different specifications of the probability of a Sudden Stop (equation (8)) and the Sudden Stop cost function (equation (9)). In order to tackle both issues, we follow Hansen and Sargent (1998), and assume that the policymaker implements a robust policy by minimizing the objective function described in equation (1) for the most conservative model, i.e., it is assumed that the policymaker faces model uncertainty (where each model is defined as a triplet of a Probit equation, a cost function and a particular size of the external shock) and chooses optimal reserve levels according to the most conservative model. ${ }^{16}$

Following this approach and for each country, we calculate optimal reserves for each combination of Probit estimations (1), (2) and (3) of Table 1, and estimated cost functions (1)

\footnotetext{
${ }^{16}$ That is, by choosing the model that yields the highest optimal reserves.
} 
and (2) of Table 2, assuming the maximum size of the external shock in both cases. ${ }^{17}$ We only use these estimations in Tables 1 and 2 because all other estimations include controls that are not significant.

Following the assumption of robust policy, we then pick the combination that yields the larger optimal reserve level, which turns out to be the most parsimonious-i.e., estimation (1) of Table 1 and estimation (1) of Table 2. In this benchmark case, net domestic liability dollarization (NetDLD) and potential changes in the real exchange rate under a sudden loss in financing of the current account deficit remain the key determinants of the probability of a Sudden Stop, while NetDLD and the fiscal balance are the key determinants of output costs of a Sudden Stop. This robust optimal level of reserves for 2007 is then compared against observed data in Figure 2.

As a first observation, notice that optimal and observed stocks of reserves are on average, in the same order of magnitude for a good number of countries. In fact, the average stock of outstanding international reserves in our sample by 2007 turns out to be $21 \%$ of GDP, while the average estimated optimal level of reserves is $25.7 \%$ of GDP. This result is remarkable considering that, unlike other studies, our methodology does not involve the calibration of parameters to match sample moments. However, it must be acknowledged that although average results are similar, there is significant variance across countries.

More importantly, our calculations suggest that over-accumulation of reserves in EMs is not obvious. Out of the 27 emerging economies considered, only 10 have observed reserves that are higher than their corresponding optimal level. Regarding Emerging Asian economies, we find that some countries like Indonesia, the Philippines and Korea are close to their optimal reserve levels, while other economies such as Thailand, Malaysia, and China seem to possess much larger reserve levels than those deemed optimal under the view presented in this paper (see Figure 2). On average, the deviation between observed reserves and optimal reserves is positive and equivalent to 14 percent of GDP, indicating over-accumulation from a precautionary standpoint. On the other hand, several Latin American countries (with the clear exception of Uruguay) lie much closer to the forty-five degree line showing optimal reserves equal to observed levels (such is the case of Argentina, Peru and Venezuela, countries that display levels

\footnotetext{
${ }^{17}$ For the Probit model, we take the maximum estimated coefficient of the set of time dummies. In the case of the cost equations, we use the maximum shock size observed in the sample used in the estimations.
} 
of observed reserves that are broadly in line with their optimal counterparts). In fact, the deviation between observed and optimal reserves for Latin American countries is on average negative and equivalent to 6 percentage points of GDP, 2.3 times smaller in absolute value than that of their Asian counterparts. It is particularly interesting to note that Peru, a dollarized economy, holds the largest level of reserves in the region. However, this can be interpreted as entirely consistent with optimality.

In the case of the Eastern European countries, we find that with the exception of Russia, all of these economies display much lower-than-optimal reserves. Indeed, the average difference between observed and optimal reserves is negative, and equivalent to 17 percentage points of GDP-almost three times larger in absolute value than that of Latin American countries-implying low self-insurance levels given their observed stocks of foreign currency liabilities. This fact opens the door for alternative explanations, suggesting that the presence of the European Union (EU) as a de-facto lender of last resort could have mitigated the perceived need for selfinsurance.

Yet another group can be identified where observed reserves exceed optimal reserves, with countries such as Russia and Nigeria, who are traditional oil exporters. Oil-exporting countries may accumulate reserves for purposes other than precautionary ones, such as accumulating the proceeds of oil for inter-temporal smoothing of consumption of oil resources across generations.

The fact that some groups of countries display much larger, or much lower levels of reserves relative to precautionary-motive optimal reserves, and that other motives discussed above may be affecting the size of observed reserves, we study whether deviations of observed reserves from precautionary-motive optimal reserves are in any way associated with perceived EU lenderof-last resort policies, oil consumption smoothing, or mercantilist purposes. To this avail, we run a regression of reserve deviations-observed reserved minus optimal reserves-against the share of EU foreign bank lending in domestic credit to the private sector in each country-in an attempt to capture perceived lender of last resort comfort-as well as a measure indicating the relevance of oil production-proxied by the oil trade balance as a share of GDP. We also include deviations of the real exchange rate from its previous five-year-average to account for the fact that countries 
with a mercantilist approach may want to hold an aggressively depreciated real exchange rate to increase exports and accumulate further reserves. ${ }^{18}$

Results are shown in Table 4, and they indicate that, indeed, countries that profusely use EU foreign lending are prone to holding lower amounts of reserves relative to optimal levels, as indicated by the negative and significant coefficient accompanying the variable measuring reliance on EU bank lending. The coefficient accompanying the measure of oil exporting relevance turns out to be positive and significant, showing that oil producers tend to hoard more reserves than those deemed optimal from a precautionary standpoint. However, the proxy for real exchange misalignment does not turn out to be significant.

Overall, these results suggest that, on average, Latin American and Asian countries were better positioned in 2007 to weather Sudden Stops relative to Eastern European economies.

Coincidentally, the results are consistent with the relative performance of these economies in the aftermath of the 2008 US financial crisis, after which Latin America and East Asia came out relatively unscathed, while Eastern Europe fell into deep recession.

From a more general perspective, it is important to notice that our analysis compares the optimal level of hard currency liquidity with the sources owned by the country, i.e. international reserves. In general, when deciding how many reserves to hold, policy makers may consider alternative sources that could be tapped should a liquidity crisis hit the economy. For instance, in several cases-and particularly so in financial centers such as Uruguay-banks may hold large levels of reserves to meet potential dollar deposit withdrawals, which could be included in measures of total foreign currency reserves. Moreover, policy makers may expect to access funds from multilateral institutions.

In the present context, this consideration takes particular importance. After the 2008 financial crisis, multilateral institutions, particularly the IMF, have taken a more active role as Lenders of Last Resort via provision of Flexible Credit Lines (FCL), which should be added to a country's stock of international reserves. However, for this to be the case, FCL lines would have to be

\footnotetext{
${ }^{18}$ This type of measure is often used in the empirical literature to approximate misalignments on the real exchange rate (see for example IMF (2011), Goldstein (2005)). Testing of alternative indicators of the mercantilist motive-like different measures of misalignments in the real exchange rate (Ghosh et al., 2012) and excess exports (Aizenman and Lee, 2005)- is left for future research.
} 
viewed as "permanently accessible", something that may not be perceived as such until these lines are sufficiently institutionalized in the international financial architecture.

How about more recent estimates of optimal reserves? Available data allow us to extend the assessment of international reserves adequacy to 2010. In this case, and for the same set of countries, we compute optimal reserves prescribed by our methodology and compare them against observed stocks (see Figure 4). ${ }^{19}$ Unlike previous results, we find that with the exception of Korea, Malaysia and Thailand, all other countries in our sample display lower-than-optimal reserves. While observed reserves remain relatively constant on average, the stock of optimal reserves has increased. To explain the latter, we analyze the changes in risk factors (namely, 1- $\omega$ , Gross DLD and the government budget balance) between 2007 and 2010 (see Figure 5). We find that all risk factors have increased in Latin America and Asia. In Latin America, the current account balance has changed from positive to negative, while the average government balance has deteriorated. In the case Europe, the observed reduction in the current account deficit relative to the absorption of tradable goods (or 1- $\omega$ in our model) is more than compensated by the deterioration of the government budget balance and the increase in Gross DLD.

One important factor to consider when interpreting these results is that the effects of the global financial crisis have not yet dissipated completely. In particular, most countries implemented significant countercyclical fiscal policies that, in most cases, have not been fully reverted. Additionally, lower post-crisis growth in developed economies and the consequent weaker external demand has contributed to a deterioration of current accounts in emerging markets. If this global setting were to remain in the medium term, then results highlight the need to improve fiscal positions and to increase access to liquidity, either through reserve accumulation and/or by securing access to international resources.

\section{Conclusions}

This paper has explored the optimality of International Reserve holdings in terms of a parsimonious model in which reserves lower the probability of Sudden Stop and its attendant costs. The estimated model, which assumes that central banks maximize the objective function that our model employs to compute optimal reserves, is not calibrated to match observed

\footnotetext{
${ }^{19}$ Due to lack of data, China and Slovakia are not included in this exercise.
} 
reserves levels. Therefore, there is no a priori reason for our concept of international reserves to be in line with observed holdings. Remarkably, however, under robust policy choices as described above, average observed reserves holdings are not distant from optimal reserve holdings prescribed by the model. This suggests that, as a general rule, variables like currencydenomination mismatch and current account deficits are taken into account by policymakers in determining the level of International Reserves.

However, there are large discrepancies from the standpoint of individual economies, pointing to the existence of other motives for reserve accumulation. Those motives may cut across most economies in our sample but they may also involve idiosyncratic factors and objectives. As a matter of fact, further analysis of differences between observed reserves and precautionarymotive optimal reserves indicates that the perceived presence of a lender of last resort, or characteristics such as being a large oil producer, may also affect the choice of reserve levels. Moreover, our analysis barely touches upon the so-called neo-mercantilist motive that might induce reserve accumulation as policymakers attempt to ensure trade competitiveness by manipulating the exchange rate during a capital-inflow episode, but find no clear evidence for this motive. ${ }^{20}$ Other possible idiosyncratic factors, not captured in this study, are actual or potential credit lines from institutions such as the IMF and the Fed. We plan to tackle these challenging issues in more detail in a follow-up paper.

\footnotetext{
${ }^{20}$ This issue, however, deserves further testing with alternative measures of mercantilist policies.
} 


\section{References}

Aizenman, Joshua, and Jaewoo Lee (2005), "International Reserves: Precautionary Vs. Mercantilist Views, Theory, and Evidence,” IMF Working Paper 05/198.

Aizenman, Joshua, and Nancy Marion (2002), "The High Demand For International Reserves In the Far East: What is Going On?," Journal of The Japanese and International Economies, Vol. 17, pp. 370-400.

Aizenman, Joshua, and Nancy Marion (2004), "International Reserve Holdings With Sovereign Risk and Costly Tax Collection,” Economic Journal 114, 569-591.

Ben-Bassat, Avraham and Daniel Gottlieb (1992), "Optimal International Reserves and Sovereign Risk," Journal of International Economics 33, 345-362.

Calvo, Guillermo A., Izquierdo, Alejandro, and Luis F. Mejía (2008), "Systemic Sudden Stops: The Relevance of Balance-Sheet Effects and Financial Integration" NBER Working Paper 14026.

Dooley, Michael P., Folkerts-Landau, David, and Peter Garber (2004), “The Revived Bretton Woods System: The Effects of Periphery Intervention and Reserve Management on Interest Rates and Exchange Rates in Center Countries" NBER Working Paper 10332.

Durdu, C. Bora, Mendoza, Enrique G. and Marco E. Terrones (2007), "Precautionary Demand for Foreign Assets in Sudden Stop Economies: An Assessment of the New Merchantilism", NBER Working Paper 13123.

Flood, Robert, and Nancy Marion (2002), "Holding International Reserves In an Era of High Capital Mobility," in Susan M. Collins and Dani Rodrik eds., Brookings Trade Forum 2001, 1-47 (Brookings Institution Press, Washington DC).

Frenkel, Jacob and Boyan Jovanovic. (1981), "Optimal international reserves: a stochastic Framework," Economic Journal 91, 507-514.

Garcia, Pablo S., and Claudio Soto (2004), "Large Hoarding of International Reserves: Are they worth it?", Central Bank of Chile Working Paper No.299.

Goldstein, Morris (2005), "What Might the Next Emerging-Market Financial Crisis Look Like?,"Working Paper Series WP05-7, Peterson Institute for International Economics.

Gonçalves, Fernando (2007), "The Optimal Level of Foreign Reserves in Financially Dollarized Economies: The Case of Uruguay," IMF Working Paper WP/07/265. 
Ghosh, Atish R., Jonathan D. Ostry and Charalambos G. Tsangarides (2012), "Shifting Motives: Explaining the Buildup in Official Reserves in Emerging Markets since the 1980s,"," IMF Working Paper 12/34.

Hansen, Lars P., and Thomas J. Sargent (1998), “Alternative Representation of Discounted Robust Linear Quadratic Control,” Working Paper.

Heller, Robert H. (1966), “Optimal International Reserves,” Economic Journal 76, 296-311. International Monetary Fund (2011), Regional Economic Outlook: Western Hemisphere Watching Out for Overheating. (Washington, April).

Jeanne, Olivier and Romain Rancière (2006), "The Optimal Level of International Reserves for Emerging Market Countries: Formulas and Applications", IMF Working Paper $06 / 229$.

Jeanne, Olivier and Romain Rancière (2009), "The Optimal Level of International Reserves For Emerging Market Countries a New Formula and Some Applications", updated mimeo. Jeanne, Olivier (2007), "International Reserves in Emerging Market Countries: Too Much of a Good Thing?", in Brookings Papers on Economic Activity 1, W. C. Brainard and G. L. Perry eds., pp. 1-55 (Brookings Institution, Washington DC).

Lee, Jaewoo (2004), "Insurance Value of International Reserves: An Option Pricing Approach", IMF Working Paper WP/04/175.

Miller, Merton and Daniel Orr (1966), "A model of the demand for money by firms," Quarterly Journal of Economics 80, 413-435.

Ortiz, Alberto, Ottonello, Pablo, Sturzenegger, Federico, and Ernesto Talvi (2009), "Monetary and Fiscal Policies in a Sudden Stop: Is Tighter Brighter?" in Dealing with an International Credit Crunch: Policy Responses to Sudden Stops in Latin America, E. Cavallo and A. Izquierdo eds., (Inter-American Development Bank, Washington DC). Ruiz-Arranz, Marta, and Milan Zavadjil (2008), “Are Emerging Asias's Reserves Really Too High?”, IMF Working Paper WP/08/192. 
Table 1: PROBIT models

\begin{tabular}{|c|c|c|c|c|c|c|c|c|c|c|c|}
\hline & $(1)$ & (2) & (3) & (4) & (5) & (6) & (7) & $(8)$ & (9) & (10) & (11) \\
\hline$(1-\omega)_{t-1}$ & $\begin{array}{c}1.430 * * * \\
(0.529)\end{array}$ & $\begin{array}{c}1.925 * * * \\
(0.720)\end{array}$ & $\begin{array}{c}2.119 * * * \\
(0.721)\end{array}$ & $\begin{array}{c}2.391 * * * \\
(0.738)\end{array}$ & $\begin{array}{c}2.340 * * * \\
(0.737)\end{array}$ & $\begin{array}{c}2.301 * * * \\
(0.745)\end{array}$ & $\begin{array}{c}2.068 * * * \\
(0.727)\end{array}$ & $\begin{array}{c}1.974 * * * \\
(0.738)\end{array}$ & $\begin{array}{c}1.969 * * * \\
(0.738)\end{array}$ & $\begin{array}{c}1.967 * * * \\
(0.740)\end{array}$ & $\begin{array}{c}1.601 * * \\
(0.800)\end{array}$ \\
\hline Net DLD $_{\mathrm{t}-1}$ & $\begin{array}{c}1.594 * * * \\
(0.513) \\
\end{array}$ & $\begin{array}{c}3.404 * * * \\
(0.850) \\
\end{array}$ & $\begin{array}{c}3.253^{* * * *} \\
(0.945) \\
\end{array}$ & $\begin{array}{c}3.203^{* * *} \\
(0.921) \\
\end{array}$ & $\begin{array}{c}3.137 * * * \\
(0.922) \\
\end{array}$ & $\begin{array}{c}3.126^{* * *} \\
(0.924) \\
\end{array}$ & $\begin{array}{c}2.750 * * * \\
(0.882) \\
\end{array}$ & $\begin{array}{c}2.547 * * * \\
(0.879) \\
\end{array}$ & $\begin{array}{c}2.532 * * * \\
(0.879) \\
\end{array}$ & $\begin{array}{c}2.504 * * * \\
(0.883) \\
\end{array}$ & $\begin{array}{r}2.536 \text { *** } \\
(0.897) \\
\end{array}$ \\
\hline Portfolio Int $\mathrm{t}_{\mathrm{t}-1}$ & & $\begin{array}{c}-5.221 * * * \\
(1.536)\end{array}$ & $\begin{array}{c}20.36 * * * \\
(6.926)\end{array}$ & $\begin{array}{c}19.19^{* * * *} \\
(6.734)\end{array}$ & $\begin{array}{c}20.46 * * * \\
(7.031)\end{array}$ & $\begin{array}{c}19.53^{* * *} \\
(7.115)\end{array}$ & $\begin{array}{c}19.21 * * * \\
(6.963)\end{array}$ & $\begin{array}{l}16.56^{* * *} \\
(6.726)\end{array}$ & $\begin{array}{c}16.57 * * \\
(6.734)\end{array}$ & $\begin{array}{c}16.37 * * \\
(6.770)\end{array}$ & $\begin{array}{c}15.82 * * \\
(6.804)\end{array}$ \\
\hline$\left(\text { Portfolio Int } t_{t-1}\right)^{2}$ & & & $\begin{array}{c}-153.3^{* * * *} \\
(50.420) \\
\end{array}$ & $\begin{array}{c}-145.1 * * * \\
(49.240) \\
\end{array}$ & $\begin{array}{c}-146.8 * * * \\
(49.910) \\
\end{array}$ & $\begin{array}{c}-141.0^{* * * *} \\
(49.620) \\
\end{array}$ & $\begin{array}{c}-138.9^{* * * *} \\
(48.840) \\
\end{array}$ & $\begin{array}{c}-121.3^{* * * *} \\
(46.770) \\
\end{array}$ & $\begin{array}{c}-121.6^{* * * *} \\
(46.880) \\
\end{array}$ & $\begin{array}{l}-121.0 * * \\
(47.130) \\
\end{array}$ & $\begin{array}{c}-114.5^{* *} \\
(47.120) \\
\end{array}$ \\
\hline FDI Int $t_{t-1}$ & & & & $\begin{array}{l}-0.181 \\
(0.595) \\
\end{array}$ & $\begin{array}{l}-0.165 \\
(0.592) \\
\end{array}$ & $\begin{array}{l}0.0346 \\
(0.602) \\
\end{array}$ & $\begin{array}{c}-0.00724 \\
(0.582) \\
\end{array}$ & $\begin{array}{l}0.0688 \\
(0.593) \\
\end{array}$ & $\begin{array}{c}0.067 \\
(0.593) \\
\end{array}$ & $\begin{array}{l}0.0738 \\
(0.595) \\
\end{array}$ & $\begin{array}{l}-0.043 \\
(0.613) \\
\end{array}$ \\
\hline Developing $_{t-1}$ & & & & & $\begin{array}{c}0.323 \\
(0.455) \\
\end{array}$ & $\begin{array}{c}0.308 \\
(0.457) \\
\end{array}$ & $\begin{array}{c}0.344 \\
(0.431) \\
\end{array}$ & $\begin{array}{c}0.391 \\
(0.432) \\
\end{array}$ & $\begin{array}{c}0.384 \\
(0.431) \\
\end{array}$ & $\begin{array}{c}0.443 \\
(0.452) \\
\end{array}$ & $\begin{array}{c}0.268 \\
(0.500) \\
\end{array}$ \\
\hline TOT growth ${ }_{\mathrm{t}-1}$ & & & & & & $\begin{array}{l}-0.258 \\
(0.738)\end{array}$ & $\begin{array}{l}-0.297 \\
(0.756)\end{array}$ & $\begin{array}{l}-0.602 \\
(0.782)\end{array}$ & $\begin{array}{l}-0.595 \\
(0.783)\end{array}$ & $\begin{array}{c}-0.58 \\
(0.785)\end{array}$ & $\begin{array}{l}-0.403 \\
(0.809)\end{array}$ \\
\hline$(\text { Gov. Balance/GDP) })_{t-1}$ & & & & & & & $\begin{array}{l}-0.005 \\
(0.005) \\
\end{array}$ & $\begin{array}{l}-0.005 \\
(0.005) \\
\end{array}$ & $\begin{array}{l}-0.005 \\
(0.005) \\
\end{array}$ & $\begin{array}{l}-0.005 \\
(0.005) \\
\end{array}$ & $\begin{array}{l}-0.005 \\
(0.005) \\
\end{array}$ \\
\hline $\mathrm{LYS3}_{\mathrm{t}-1}$ & & & & & & & & $\begin{array}{c}0.097 \\
(0.114) \\
\end{array}$ & & & \\
\hline LYS5 $_{\mathrm{t}-1}$ & & & & & & & & & $\begin{array}{c}0.060 \\
(0.074) \\
\end{array}$ & $\begin{array}{c}0.061 \\
(0.074) \\
\end{array}$ & $\begin{array}{c}0.059 \\
(0.076) \\
\end{array}$ \\
\hline$(\mathrm{M} 2 / \text { Reserves })_{\mathrm{t}-1}$ & & & & & & & & & & $\begin{array}{c}0.005 \\
(0.011) \\
\end{array}$ & $\begin{array}{c}0.007 \\
(0.012) \\
\end{array}$ \\
\hline$(\text { For. Debt/GDP) })_{t-1}$ & & & & & & & & & & & $\begin{array}{c}0.000 \\
(0.000) \\
\end{array}$ \\
\hline Constant & $\begin{array}{c}-3.281 * * * \\
(0.332)\end{array}$ & $\begin{array}{c}-3.456^{* * *} \\
(0.460)\end{array}$ & $\begin{array}{c}-3.824 * * * \\
(0.496)\end{array}$ & $\begin{array}{c}-3.708 * * * \\
(0.520)\end{array}$ & $\begin{array}{c}-4.008 * * * \\
(0.677)\end{array}$ & $\begin{array}{c}-4.036 * * * \\
(0.684) \\
\end{array}$ & $\begin{array}{c}-3.886^{* * * *} \\
(0.662)\end{array}$ & $\begin{array}{c}-4.023 * * * \\
(0.704)\end{array}$ & $\begin{array}{c}-4.032^{* * *} \\
(0.713)\end{array}$ & $\begin{array}{c}-4.114 * * * \\
(0.739)\end{array}$ & $\begin{array}{c}-3.877 \text { *** } \\
(0.756)\end{array}$ \\
\hline Observations & 1,101 & 951 & 951 & 941 & 941 & 922 & 868 & 814 & 814 & 813 & 677 \\
\hline \# Countries & 110 & 95 & 95 & 94 & 94 & 90 & 84 & 83 & 83 & 83 & 72 \\
\hline
\end{tabular}

Standard errors in parentheses. *** $\mathrm{p}<0.01, * * \mathrm{p}<0.05, * \mathrm{p}<0.1$. Time dummies included in all regressions. 
Table 2: Cost Equations

\begin{tabular}{|c|c|c|c|c|c|c|c|c|}
\hline & (1) & (2) & (3) & (4) & (5) & (6) & (7) & (8) \\
\hline \multirow[t]{2}{*}{$(1-\omega)_{\mathrm{T}}$} & -0.188 & -0.223 & -0.222 & -0.200 & -0.195 & -0.197 & -0.229 & -0.254 \\
\hline & $(0.137)$ & $(0.175)$ & $(0.178)$ & $(0.180)$ & $(0.187)$ & $(0.187)$ & $(0.190)$ & $(0.200)$ \\
\hline \multirow[t]{2}{*}{ Net $\mathrm{DLD}_{\mathrm{T}}$} & $0.150 * *$ & $0.177 * * *$ & $0.176 * *$ & $0.171 * *$ & $0.171 * *$ & $0.173 * *$ & $0.171 * *$ & $0.168^{*}$ \\
\hline & $(0.062)$ & $(0.063)$ & $(0.065)$ & $(0.070)$ & $(0.074)$ & $(0.074)$ & $(0.079)$ & $(0.089)$ \\
\hline \multirow[t]{2}{*}{$(\text { Gov. Balance/GDP })_{\mathrm{T}}$} & $-0.884 * * *$ & $-0.976 * * *$ & $-1.003 * * *$ & $-0.951 * *$ & $-0.945^{* *}$ & $-0.945 * *$ & $-0.981 * *$ & $-0.876 * *$ \\
\hline & $(0.209)$ & $(0.199)$ & $(0.329)$ & $(0.413)$ & $(0.437)$ & $(0.430)$ & $(0.402)$ & $(0.412)$ \\
\hline \multirow[t]{2}{*}{ Portfolio Int ${ }_{\mathrm{T}}$} & & $0.673 * *$ & $0.697 *$ & $0.816^{*}$ & 0.807 & 0.811 & $0.922 *$ & $0.960 *$ \\
\hline & & $(0.308)$ & $(0.390)$ & $(0.427)$ & $(0.488)$ & $(0.489)$ & $(0.486)$ & $(0.494)$ \\
\hline \multirow[t]{2}{*}{ FDI Int ${ }_{\mathrm{T}}$} & & & -0.011 & -0.047 & -0.048 & -0.047 & -0.057 & -0.083 \\
\hline & & & $(0.084)$ & $(0.094)$ & $(0.099)$ & $(0.098)$ & $(0.090)$ & $(0.100)$ \\
\hline \multirow[t]{2}{*}{ TOT growth ${ }_{\mathrm{T}}$} & & & & 0.111 & 0.114 & 0.111 & 0.121 & 0.229 \\
\hline & & & & $(0.193)$ & $(0.194)$ & $(0.197)$ & $(0.201)$ & $(0.228)$ \\
\hline \multirow[t]{2}{*}{$\mathrm{LYS}_{\mathrm{T}}$} & & & & & -0.005 & & & \\
\hline & & & & & $(0.018)$ & & & \\
\hline \multirow[t]{2}{*}{$\mathrm{LYS5}_{\mathrm{T}}$} & & & & & & -0.002 & -0.001 & 0.005 \\
\hline & & & & & & $(0.011)$ & $(0.012)$ & $(0.013)$ \\
\hline \multirow[t]{2}{*}{$(\mathrm{M} 2 / \text { Reserves })_{\mathrm{T}}$} & & & & & & & -0.002 & -0.003 \\
\hline & & & & & & & $(0.002)$ & $(0.002)$ \\
\hline \multirow[t]{2}{*}{$(\text { For. Debt/GDP })_{\mathrm{T}}$} & & & & & & & & $2.44 \mathrm{E}-05$ \\
\hline & & & & & & & & $(0.000)$ \\
\hline \multirow[t]{2}{*}{ Shock Size } & $0.006^{*}$ & $0.008^{* *}$ & $0.008 * *$ & $0.009 * *$ & $0.009^{*}$ & $0.009^{*}$ & $0.008^{*}$ & $0.009^{*}$ \\
\hline & $(0.003)$ & $(0.004)$ & $(0.004)$ & $(0.004)$ & $(0.004)$ & $(0.005)$ & $(0.005)$ & $(0.005)$ \\
\hline \multirow[t]{2}{*}{ Constant } & $0.049 * *$ & 0.007 & 0.006 & 0.009 & 0.020 & 0.015 & 0.031 & 0.020 \\
\hline & $(0.024)$ & $(0.036)$ & $(0.037)$ & $(0.034)$ & $(0.066)$ & $(0.071)$ & $(0.074)$ & $(0.086)$ \\
\hline Observations & 37 & 35 & 35 & 34 & 33 & 33 & 33 & 31 \\
\hline R-squared & 0.41 & 0.46 & 0.46 & 0.47 & 0.46 & 0.46 & 0.47 & 0.52 \\
\hline
\end{tabular}

Robust standard errors in parentheses. *** $\mathrm{p}<0.01, * * \mathrm{p}<0.05, * \mathrm{p}<0.1$ 
Table 3: Sample of Countries

\begin{tabular}{cccc}
\hline Emerging Asia & Latin America & Emerging Europe, & Other Emerging \\
& & & \\
\hline China & Argentina & Bulgaria & Egypt \\
Indonesia & Brazil & Czech Republic & Nigeria \\
Korea & Chile & Hungary & South Africa \\
Malaysia & Colombia & Poland & \\
Philippines & Dominican Rep. & Romania & \\
Thailand & Mexico & Russia & \\
& Peru & Slovakia & \\
& Uruguay & Turkey & \\
& Venezuela & Ukraine & \\
\hline
\end{tabular}

Table 4: Explaining Deviations from Optimal

\begin{tabular}{cccc}
\hline & $(1)$ & $(2)$ & $(3)$ \\
\hline Oil Balance/GDP & $0.696^{* * * *}$ & $0.674^{* * *}$ & $0.738^{* * *}$ \\
& $(0.226)$ & $(0.269)$ & $(0.239)$ \\
\hline EU Foreign Bank & $-0.175^{* *}$ & $-0.184^{* *}$ & $-0.174^{* *}$ \\
Lending & $(0.068)$ & $(0.071)$ & $(0.069)$ \\
\hline REER Gap & & 0.252 & \\
& & $(0.331)$ & \\
\hline No Access to ILOR & & & -0.0402 \\
& & & $(0.066)$ \\
\hline Constant & 0.0215 & 0.0741 & 0.0241 \\
& $(0.053)$ & $(0.066)$ & $(0.056)$ \\
\hline Observations & 27 & 23 & 27 \\
R-squared & 0.312 & 0.322 & 0.314 \\
\hline
\end{tabular}




\section{Figure 1: Output Costs of Systemic Sudden Stops}

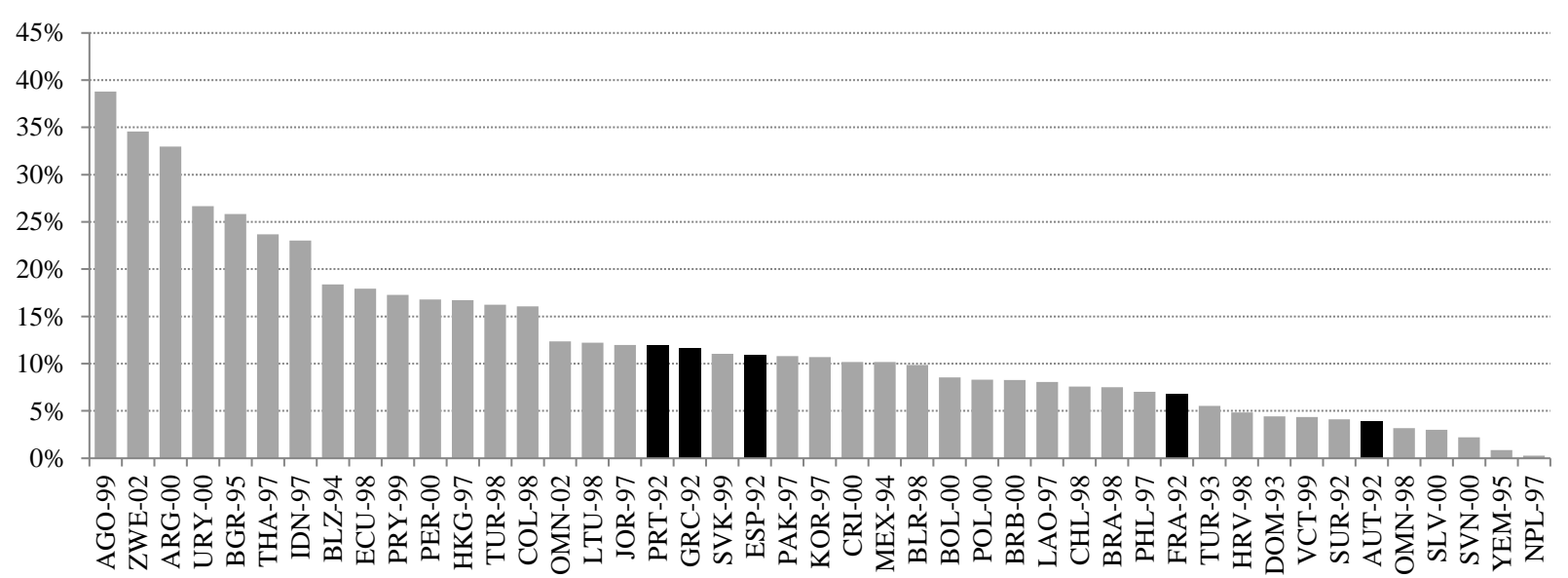

Note: Black bars indicate identified episodes in Developed countries.

Figure 2: Optimal vs. Observed Reserves as of 2007 (\% of GDP)

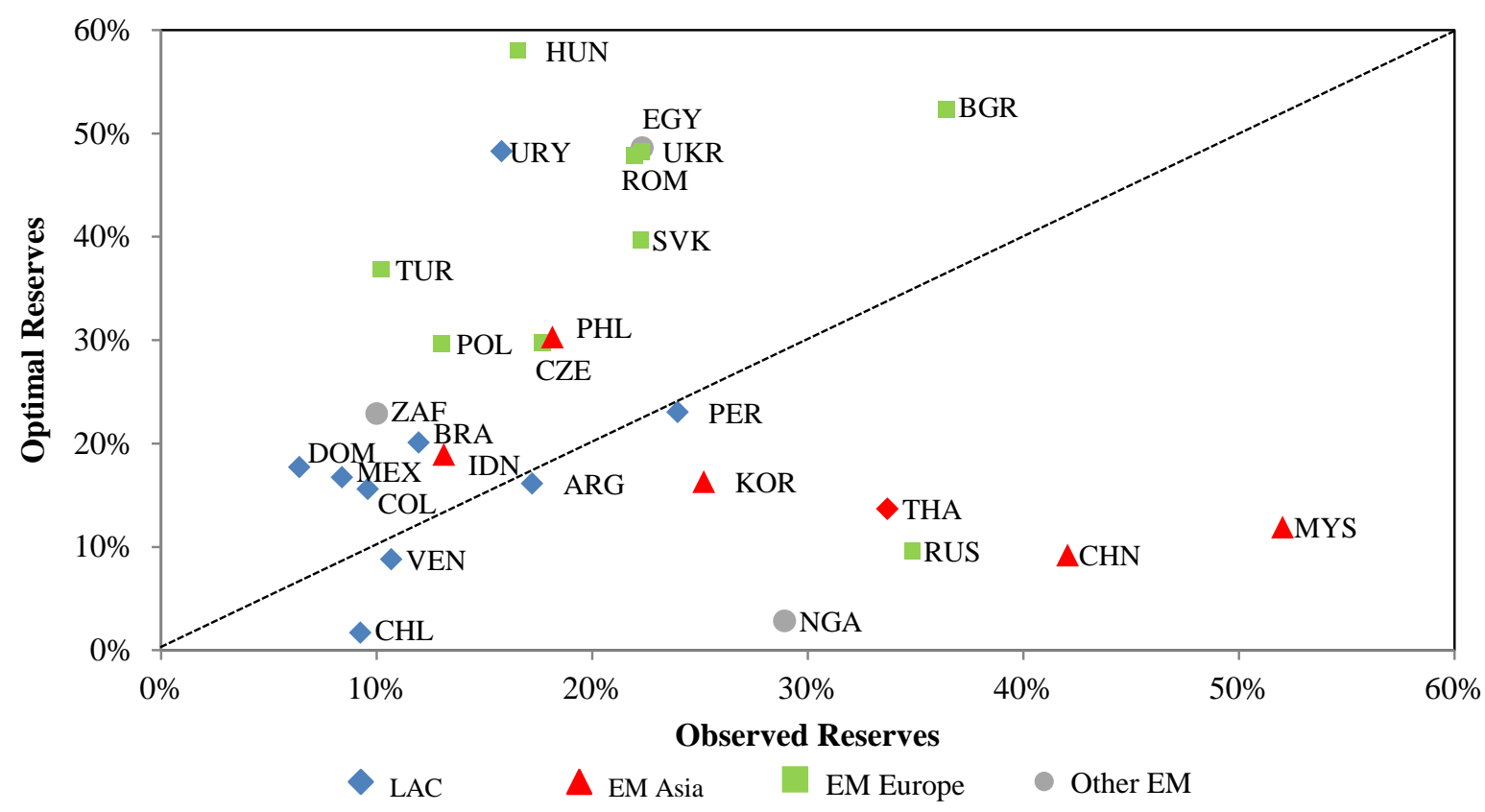


Figure 3: Observed minus Optimal Reserves (2007, \% of GDP)

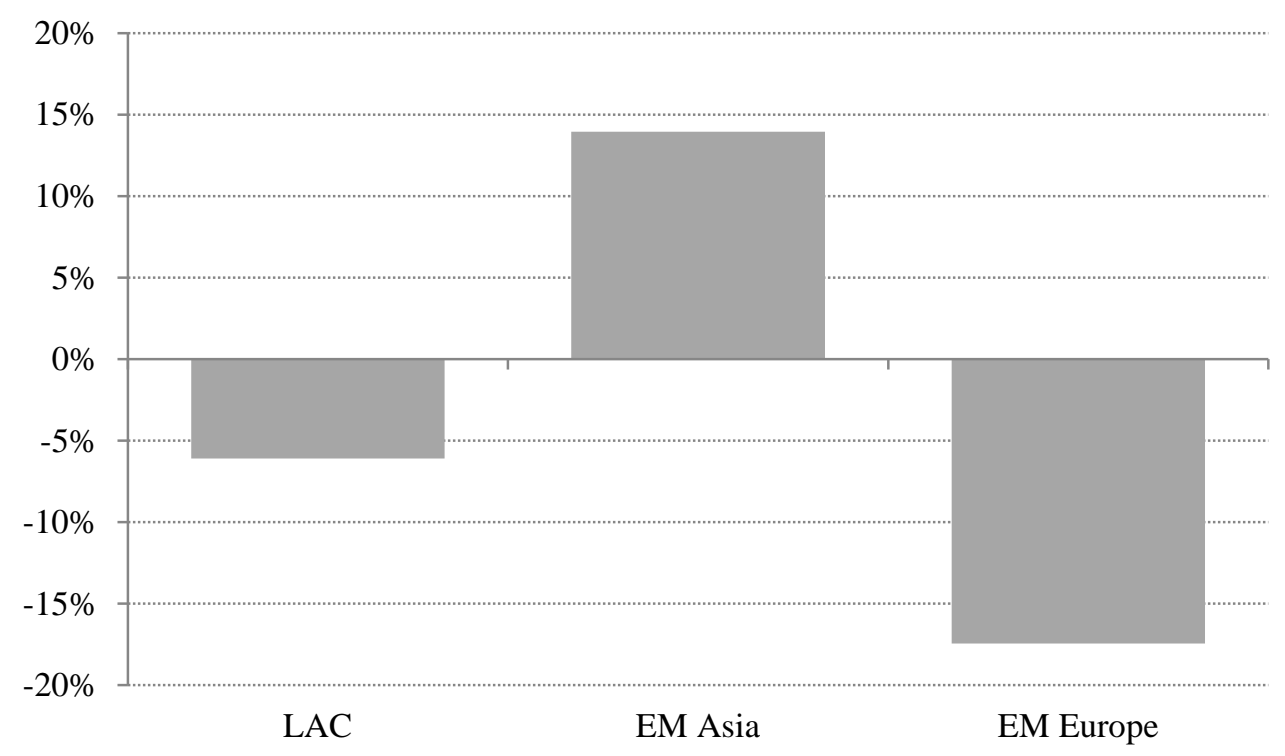

Figure 4: Optimal vs. Observed Reserves as of 2010 (\% of GDP)

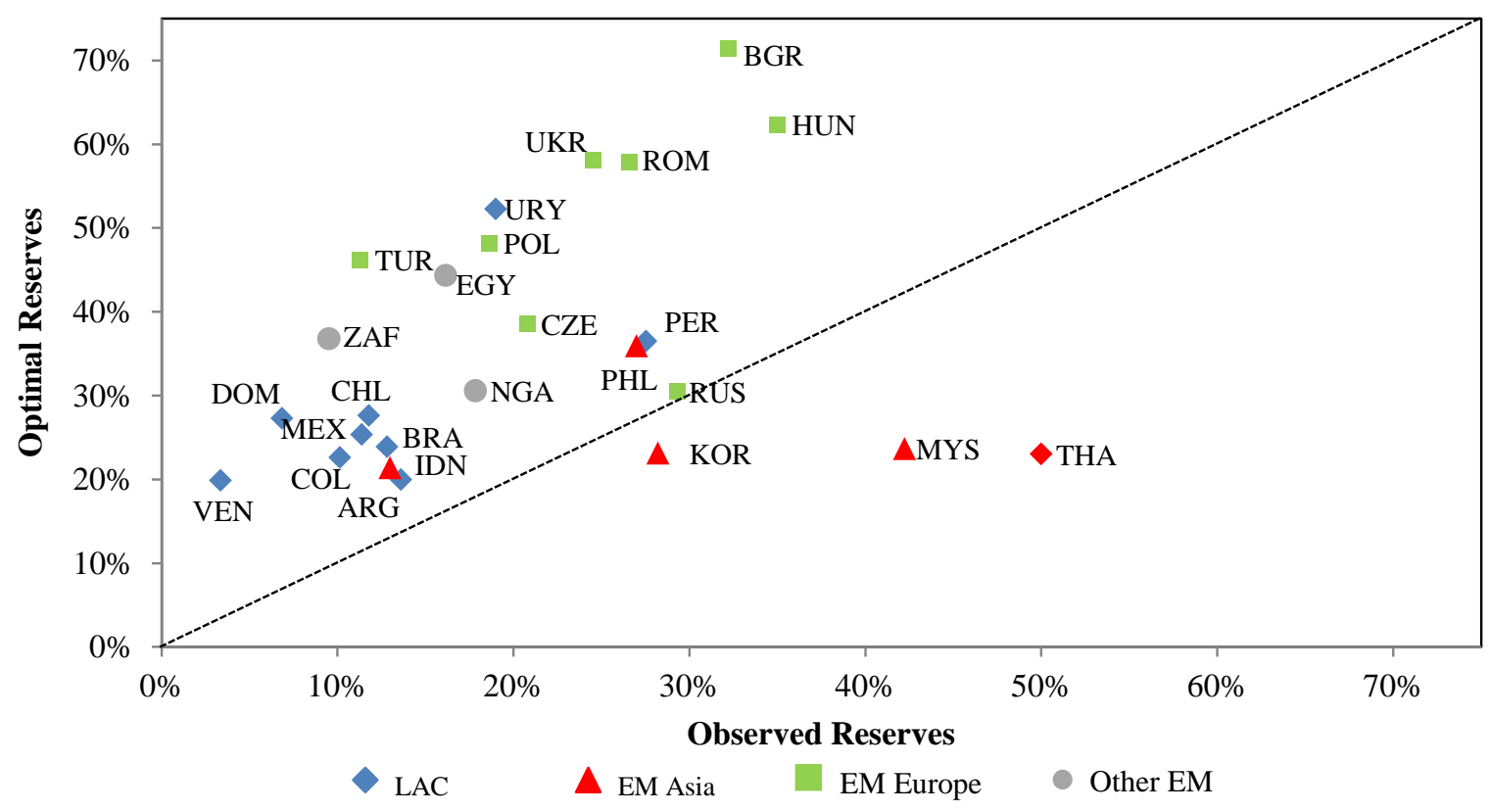


Figure 5: Risk factors between 2007 and 2010
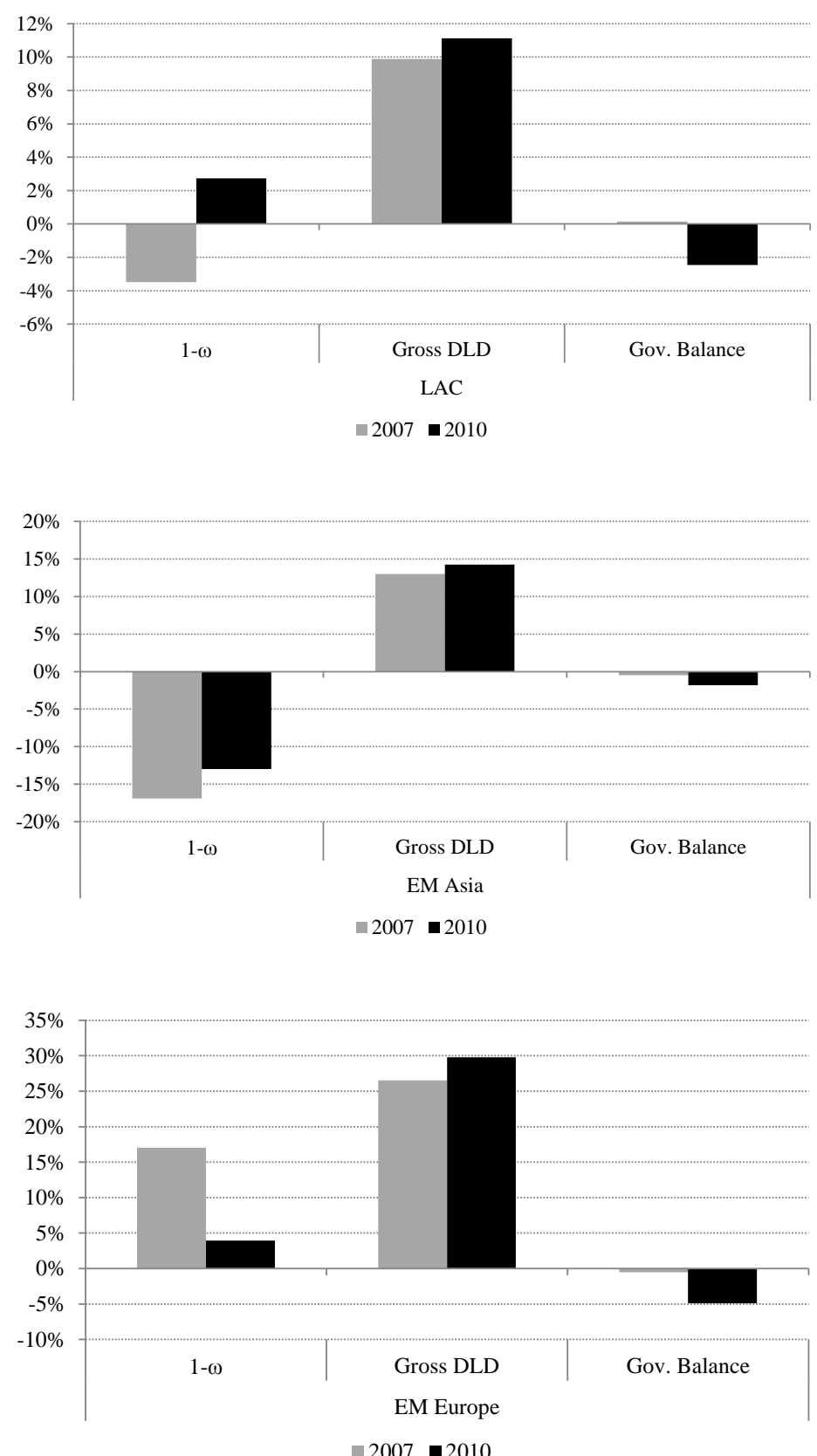